\title{
A Study of Zhejiang Industrial Clusters' Influence on Export by two cases
}

\author{
Chunxiang Liu ${ }^{1}$ Qizhen Yang ${ }^{1}$ \\ ${ }^{1}$ Business School of Zhejiang Wanli University, Ningbo City, Zhejiang Province, China
}

\begin{abstract}
As there are increasing enterprises in Zhejiang industrial clusters, their influence on export have drawn great attention from the public. This paper has explored Zhejiang industrial clusters' influences on export by two cases and provided references to other scholars.
\end{abstract}

Keywords: Zhejiang industrial clusters; influence; export; Case analysis

\section{General information on Zhejiang industrial clusters and export}

The foreign trade in Zhejiang has been developed and enhanced gradually, which is closely related to Zhejiang industrial clusters. Zhejing industrial clusters' influences on export are mainly reflected in following three aspects:

Firstly, the development of Zhejiang industrial clusters gives a strong impetus to the enhancement of product exports and dependence on foreign trade. Zhejiang industrial clusters changed its mode of development from copying at the beginning to innovation later, during which the foreign trade in Zhejiang had been driven by industrial clusters and developed dramatically. Especially after China's entry into WTO, Zhejiang Province ranked top in respect of foreign trade and earnings from foreign trade. Policy Research Office of Zhejiang Provincial Committee of CPC conducted survey on the general situation of Zhejiang industrial clusters respectively in 1996, 2000 and
2004. It rose sharply in 2004 and achieved RMB 1582.6 billion, increasing by $164 \%$ compared to 2000 and $494 \%$ compared to 1996. Meanwhile, the proportion of the output value of industrial clusters to the gross industrial output value of Zhejiang Province was raised from $49 \%$ in 2000 to $64 \%$ in 2004 with a growth rate of 15 percentage point. Driven by the fast development of industrial clusters, exports of Zhejiang Province were dramatically developed. The value of exports in 2010 was 17.8 times that in 1997.

Meanwhile, due to the development of industrial clusters, Zhejiang Province was gradually featured with export-oriented economy. The dependence on foreign trade was only $15.49 \%$ in 1996 , but went up to $41.32 \%$ in 2004 with a growth rate of 26 percentage point. After 2004, the dependence on foreign trade kept rising and exceeds $50 \%$ in 2006 . It fell down in 2009 due to the financial crisis. The fast growth of exports in Zhejiang was closely related to industrial clusters. In 2010, there were 601 industrial clusters in Zhejiang and their value of exports reached RMB 321.1 billion, accounting for $58 \%$ of the gross industrial output value of that year. Amongst, 171 industrial clusters' exports took up more than $30 \%$ of their annual output value, and 103 industrial clusters' exports even took up more than $50 \%$ of their annual output value.

Secondly, the mode of exports by Zhejiang industrial clusters is decisive to the mode of exports in Zhejiang Province. 
As we know, Zhejiang industrial clusters are mostly engaged in the manufacturing industry. Those industrial clusters are characterized by low content of technology. They normally develop from small workshops and from the professional system of labor division and cooperation.

Finally, the structure of export commodities of Zhejiang industrial clusters is decisive to exports of Zhejiang Province. In 2010, the textile industry, the textile, garments, shoes and hats manufacturing industry as well as the electrical machinery and equipment manufacturing industry ranked top 3 in all Zhejiang industrial clusters. In respect of export delivery value, industrial clusters with the export delivery value of more than RMB 13 billion include Yiwu commodities, Shaoxing textiles, Xiaoshan textiles, Yongkang hardware, Cixi home appliances, Zhenhai chemicals and new materials, Zhuji hosiery, NBFTZ liquid crystal and photoelectricity and Yinzhou textile. It can learned that Zhejiang industrial clusters are mainly concerned with textile, garments and home appliances in terms of both product structure and export structure.

Therefore, Zhejiang industrial clusters are particularly associated with exports in Zhejiang in connection with scale, trading mode and commodities' structure. It is the expansion of industrial clusters that remarkably increases exports in Zhejiang.

\section{Case analysis on Zhejiang indus- trial clusters' influences on export}

\subsection{Case of export development through specialized division of la- bor by industrial clusters}

Specialized division of labor in industrial clusters enables each company to make use of their strength on production and scale as well as motivate each entrepreneur to provide better products and ser- vices. After labor division, industrial clusters improve production efficiency, reduce production cost, enhance international competitiveness of products in industrial clusters, and increase exports. Datang hosiery industry, as a regionally characteristic industry cluster, has been a giant socialized factory and an integrated production system based on labor division and market regulation with the structure of "small commodities, large market".

Datang Town in Zhuji City, Zhejiang Province is world-famous as the "Capital of Hosiery of China". By the end of 2003, an industrial chain centering on Datang Town had been formed and there had been more than 100 companies with the annual income from sales of RMB 5 million and more than 70 hosiery companies with the right of self-managed import and export whose products were exported to more than 40 countries and regions including Europe, USA, Middle East and South America. At the end of 2010, the annual output value of Datang hosiery industry exceeded RMB 23 billion and the export delivery value reached RMB 5.2 billion which were rising sharply.

Companies in Datang Town are intricately linked with the hosiery industry, which makes them form a network structure. The labor division of Datang hosiery industry ranges from production and marketing of raw materials for socks to sales and maintenance of hosiery machines (and their parts), patterns and sample making, hosiery knitting, sewing, dyeing, shaping, printing and packaging as well as sales of finished products. It has constructed a completely regional production system. In each chain of the hosiery manufacturing, there are many competitive companies to increase efficiency and generate the effective economics of scale, which reduces production cost of hosiery and raises competitiveness. 
A network system of specialized labor division and cooperation has been naturally formed. The complete network of labor division, the high-efficient production system and the perfect supporting services embody the international competitiveness of Datang hosiery industry. Due to segmentation of the international hosiery market in terms of pattern, Datang hosiery industry is adaptive to hosiery markets requiring small batches and diversified patterns in a flexible organization form and takes up more shares in the international market. The output of Datang hosiery industry accounts for $65 \%$ of the national hosiery output and $1 / 3$ of the global hosiery output, which means that everyone in the world has a pair of socks produced in Datang. According to statistics by the Foreign Trade and Economic Cooperation of Zhuji, the export value of hosiery (mainly produced by Datang hosiery companies in Zhuji) achieved USD 76.77 million in 2003 increased by $119.8 \%$. In 2010 , the export value of hosiery exceeded USD 300 million. These products were exported to more than 40 countries and regions including Japan, Korea, Europe and USA, showing great success in both technique and management. From the case of Datang hosiery industry, we can learn that efficiently specialized division of labor in an industrial cluster greatly raises exports.

\subsection{Case of export development through innovation in industrial clusters}

Geographical concentration and serious phenomenon of like products in an industrial cluster lead to fierce competition between companies in this cluster which have to face the survival crisis every minute and are forced to learn continuously and make innovation. Meanwhile, as companies in the industrial cluster understand and trust each other, they may cooperate with each other to reduce risk and production cost for mutual benefit. Thus, they enhance economic benefit, strengthen international competitiveness of the whole cluster and increase exports. We will make further explanation through the case of Yueqing low-voltage apparatus industry cluster.

Yueqing low-voltage apparatus industry cluster emerged in the late 1960s as small workshops and was basically shaped in the early 1980s. After more than 20 years' development, it has been a typical industrial cluster locally formed. This cluster incorporates more than 2000 companies (including a number of workshops) in an area of less than 50 square kilometers as the largest low-voltage apparatus base in China. It is the "Capital of Electrical Apparatuses of China". According to the latest statistical results, the annual output value of Liushi low-voltage apparatus industry cluster reached RMB 32.5 billion in 2010 and its export delivery value was more than USD 500 million. Moreover, its exports are still increasing greatly, mainly motivated by innovation activities in this cluster.

In the first half of 1977, as a breakthrough in the sales of products, the first low-voltage apparatus store opened in Houjie Liushi. After the 3rd Plenary Session of the 11th CPC Central Committee, the mode of "store in front and factory at the back" was increased in Liushi. At that time, Liushi was unable to produce complete low-voltage apparatuses, but only able to disassemble waste electrical appliances and assemble simple parts. Due to low content of technology and serious homogeneity of products, companies were vying for customers by lowering prices. The intense competition forced companies to seek for innovation in respect of production management, products and technique so as to increase benefit. Yueqing Qiujing Switches Factory, established in 1984, attracted more than 700 technicians and initiated cooperative 
relationships. It provided complete lowvoltage apparatuses for the first time and innovatively improved the productivity of low-voltage apparatuses in Yueqing. At the late 1980 s, since the prices of raw materials and labor cost were both raised, companies watered down technical requirements and cut corners by substitution of inferior raw materials for getting more profits, which caused a detrimental effect and severe loss to companies. Under the regulation and support of the government, these companies started to explore innovation. In 2010, Liushi companies invested more than RMB 215 million in technical transformation. A number of professional technicians and managers joined in these companies in the way of appointment with high salaries or technology investment, which remarkably enhanced the production, management and marketing of Liushi companies.

On the other hand, the development of Liushi low-voltage apparatus industry cluster was accompanied by innovative dissemination. As these companies were located close to each other, it was easy for them to learn. Products created by technical innovation of one company were copied and produced by other companies through labor transfer and communication, showing extensive development from one point. Moreover, upstream and downstream companies cooperatively developed new technique and new materials, jointly shared risks and profits to achieve mutual benefit.

Through fierce competition, innovation, washing out and cooperation, Liushi industrial cluster in Yueqing was expanding its scale and promoting exports. In 2010, the amount of selfmanaged exports exceeded USD 1 billion and reached USD 1.9 billion. From Liushi industrial cluster in Yueqing, we can see that innovation of the industrial cluster enhanced international competitiveness and boosted the growth of exports.

\section{Conclusion}

The development of Zhejiang industrial clusters improves dependence on Zhejiang export and foreign trade, and also decides the key trade means and the key commercial structure of Zhejiang export. Moreover, by two cases of Datang hosiery industry cluster and Yueqing lowvoltage apparatus industry cluster, it demonstrates that Zhejiang industrial clusters promote export through specific division of labor and innovation.

\section{Acknowledgements}

This paper was financially supported by the natural science subject of Zhejiang Province with the number of LQ12G03004, and the academic leaders fostering subject of Ningbo Academy of Social Science with the number of G11XK15.

\section{References}

[1] $\mathrm{Wu}$ Longhui, Hu Qiuguang, "Export Trade Effect and Analysis of Garment Industrial Clusters of Zhejiang", Commercial Research, pp. 206-211, vol.12, 2010.

[2] Krugman, P, "Increasing Returns and Economic Geography", Journal of Political Economy, pp. 483-499, vol.99, 1991.

[3] Fujita \& Thisse, "Does Geographical Agglomeration Foster Economic Growth? And Who Gains and Who Loses", the Japanese Economic Review, pp. 121-145, vol.54, 2003.

[4] Antonio Ciccone, "Agglomeration-Effects in Europe", European Economic Review, pp. 213-227, vol.46, 2002.

[5] Isard W, Location and Space Economy, New York: John Wiley, 1956. 